\title{
Description of Family Satisfaction toward Information Technology Based Family Nursing
}

\author{
Tuti Nuraini ${ }^{1}$, Rr. Tutik Sri Hariyati ${ }^{1}$, Junaiti Sahar ${ }^{2}$, Nami Kobayashi ${ }^{3}$, \\ Jajang R. Solihin ${ }^{2}$ \\ ${ }^{1}$ Departement Basic and Fundamentals Nursing, Faculty of Nursing Universitas Indonesia, Indonesia \\ ${ }^{2}$ Department Community Health Nursing, Faculty of Nursing, Universitas Indonesia, Indonesia \\ ${ }^{3}$ Department Family Nursing, Kitasato University, Japan
}

\begin{abstract}
Information technology based family nursing care is an important aspect to provide high quality nursing care. Family centered nursing care is the forefront of the community health enhancement. Nursing Information System (NIS) in community health center include development of technology based nursing documentation, and enhancement of communication between health team and family. The aim of this study was to evaluate family satisfaction toward information technology based family nursing care. Family satisfaction was measured by identify family opinion regarding the role of family nurses in providing qualified nursing care as well as their opinion regarding the needs of family nurses. Measurement was performed to 35 families who have received family nursing care based information technology as intervention group and 35 families who have not received as control group. The responses to overall satisfaction in intervention group were "very satisfied" in $14.29 \%$ and "satisfied" $80 \%$. Result of the research showed family satisfaction who have received information technology based family nursing care was higher than control group $(p=0.000)$. However, nursing information technology supported nursing care documentation, which affected the quality and continuity of family centered nursing care, and then affected the level family satisfaction.
\end{abstract}

Key words: Family satisfaction, Nursing information system

\section{Introduction}

Information technology based family nursing care is an important aspect to provide high quality nursing care. Family centered nursing care is the forefront of the community health enhancement. Information technology may facilitate coordinative, comprehensive, and cost effective family nursing care. Nursing Information System (NIS) in community health center include development of technology based nursing documentation, and enhancement of communication between health team and family.

Family nursing care through nursing documentation is a precondition for good patient and family care, effective communication and cooperation within the health care professional team (1). Nursing documentation is an important element of nursing process that is still insufficiently performed in Indonesia. Many nurses here were still lack of awareness about the public responsibility aspect of the nursing service. On the other hand, nurses were still also lack of knowledge about what to be documented and how to make a right documentation (2). A good nursing documentation based technology information to improve the quality and continuity family nursing care.

The practice of family nursing care in Indonesia is still not as expected. People really need the practice of family nursing care. This was showed by the results of research conducted in the Ratu Jaya Village, Depok, Indonesia. Level of family needs to practice family nursing service in the Ratu Jaya Village, Depok, Indonesia showed at the level very high at $97.5 \%$ (3). Good documentation was part of the aspects nursing care which was needed by the community. With good documentation, supported by sophisticated information technology can improve communication in health care. People really need good information and communication in health care. Current information technology can facilitate these needs.

However, previous research showed that the major problem of the nursing care delivery in Indonesia was that nurses did not provide nursing care according to the standard without proper nursing documentation as well (4). Many nurses in Indonesia well still lack of awareness about the public responsibility aspects of the nursing services, in addition to the inability to make a good nursing documentation. This problem could reduce the quality of nursing care given, especially at family nursing care at the level health center community district.

The informatics provides essential infrastructure for both continuous and long-term quality assessment and improvement in nursing (5). A research indicated many advantages as time saving during care planning and clear improvement in legibility and completeness of documentation. They also reported significant increase in the acceptance of computers in nursing. Many research about documentation based information technology, but there is no research that describe the level of satisfaction patient and family after accepted family nursing care 
based information technology in Indonesia. In fact, we need to evaluate whether nurses performed as expected by the service recipient.

The manual nursing documentation requires more time and energy to be completed. Paper based documentation possesses many weaknesses as it can be lost and slipped that may potentially put a nurse in the legal risk. It is also inefficient to be stored and recalled when necessary. Family nursing care through computer based nursing documentation is needed to improve the quality and continuity family nursing care.

\section{Methods}

Design study used quasi experiment method approach one group post test with control group to investigate the effect of the application of nursing documentation based information technology in central health community Kramat Jati districts, East Jakarta for increased quality and continuity family nursing care.

Sample of this study were 35 families (intervention group) which member of family accepted family nursing care with computer based documentation and 35 families (control group). We chose family in around central health community Kramat Jati districts as intervention group, because only in central health community Kramat Jati districts, East Jakarta which use information technology to documentation family nursing care. Then, we chose family in South Jakarta as control group, because have not yet use information technology to documentation family nursing care.

The research is integrated with other research which study nursing experiences to give family nursing care based information technology in nursing documentation. In this research, we study level satisfaction family which accepting family nursing care based information technology.

Data were statistically analyzed using a computer program. To analyze the test data using frequency distribution and Mann Whitney test to identify family opinion regarding the role of family nurses in providing qualified nursing care as well as their opinion regarding the needs of family nurses after received family nursing care based information technology in nursing documentation.

Instrument. The Satisfied Family in Community is a Likert-type scale to measure family satisfaction in community. The levels of satisfaction with care are determined by the degree with 20 brief statements. The answers are represented on a four point scale from 1 (very dissatisfied) to 4 (very satisfied). The scale has four subcategories confirmed by factor analysis: family nursing care, health information, information management in health care, and family expectancy. Family nursing care dimension involve the opinion family about the family nursing role had done, including a physical examination, diet, performing maintenance at-risk family members (old people, teenagers, school-age, children under five, pregnant women, and breastfeeding mother), solving health problems, and providing medical consultation. Health information dimension involve provide information about prevention and control of healthcare, changing the environment healthier, teaches healthy eating, clean lifestyle.. Information management in health care dimension involve linking with community health centers and hospitals. Other variables, which are measured against the wishes or expectations of the role of family caregivers, including family wishes that the family nurse service fees charged to the government, felt the need to visit family caregivers, get good information from family caregivers, to help care for a family member, can tell you about health problems of family caregivers, and know the results of the development of the health of every month. The levels of expectation with care are determined by the degree with 5 brief statements. Instruments was used have proven validity and reliability.

Prior to the implementation of the study, researchers informs all respondents about prosedure research to be conducted. After getting the information so all respondents signed an informed consent. This research has passed the test of ethics in nursing research through ethics committee FON-UI.

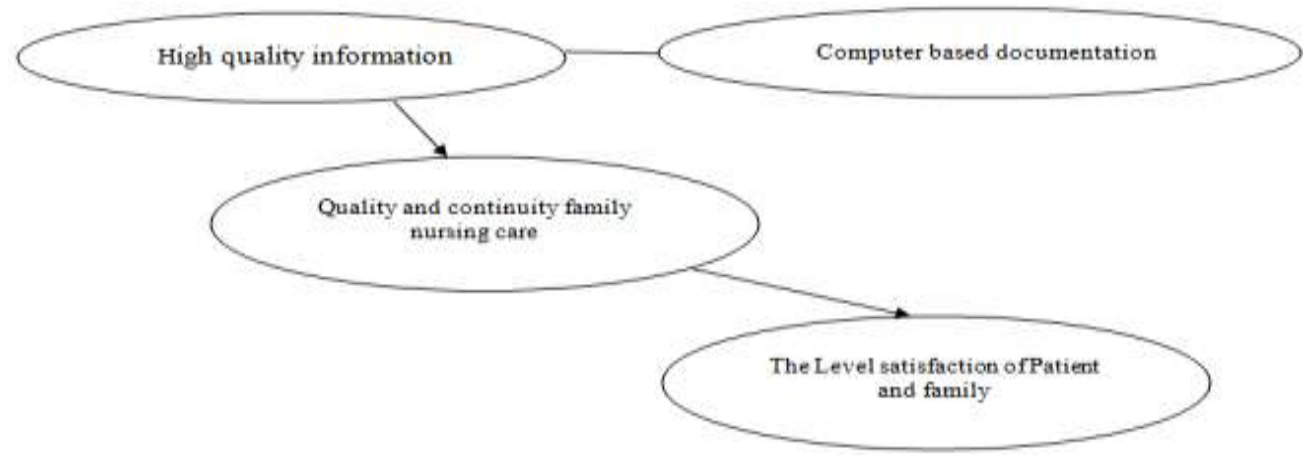

Figure 1. Conceptual framework: A good nursing documentation based technology information to improve the quality and continuity family nursing care. 


\section{Result}

The instrument of level satisfaction family satisfaction was measured by identify family opinion regarding the role of family nurses in providing qualified nursing care as well as their opinion and expectancy regarding the needs of family nurses. Measurement was performed to 35 families who have received information technology based family nursing care as intervention group and 35 families who have not received information technology based family nursing care as control group.

Table 1.

Distribution of respondents by occupation

\begin{tabular}{ccccccc}
\hline \multirow{2}{*}{ Occupation } & \multicolumn{2}{c}{ Intervention } & \multicolumn{2}{c}{ Control } & \multicolumn{2}{c}{ Total } \\
\cline { 2 - 7 } & frequency & $\%$ & frequency & $\%$ & frequency & $\%$ \\
\hline Official & 0 & 0 & 3 & 8.57 & 3 & 4.29 \\
Entrepreneur & 27 & 77.14 & 23 & 65.71 & 50 & 71.43 \\
Private & 5 & 14.29 & 7 & 20 & 12 & 17.14 \\
Retired & 3 & 8.57 & 2 & 5.7 & 5 & 7.14 \\
\hline
\end{tabular}

From Table 1, most of the respondents are self-employed work or entrepreneur, both of the group, control group $(65.71 \%)$ and the intervention group $(77.14 \%)$.

\section{Overall satisfaction.}

The distribution of level family satisfaction intervention group higher then control group. The responses to overall satisfaction in intervention group were: "very satisfied" in 14.29\% $(\mathrm{n}=5)$, "satisfied" in $80 \%(\mathrm{n}=28)$, "quite satisfied" in 5.7\% (n=2). While, responses to overall satisfaction in the control group were: "satisfied" in $5.7 \%(\mathrm{n}=2)$, "quite satisfied" in $88.57 \%(\mathrm{n}=31)$, and "less satisfied" in $5.7 \%(\mathrm{n}=2)$.

Table 2.

Distribution of respondents by family satisfaction

\begin{tabular}{ccccccc}
\hline Family & \multicolumn{2}{c}{ Intervention } & \multicolumn{2}{c}{ Control } & \multicolumn{2}{c}{ Total } \\
\cline { 2 - 7 } satisfaction & frequency & $\%$ & frequency & $\%$ & frequency & $\%$ \\
\hline Very satisfied & 5 & 14.29 & 0 & 0 & 5 & 7.14 \\
Satisfied & 28 & 80 & 2 & 5.7 & 30 & 42.86 \\
Quite satisfied & 2 & 5.7 & 31 & 88.57 & 33 & 47.14 \\
Less satisfied & 0 & 0 & 2 & 5.7 & 2 & 2.86
\end{tabular}

From Table 2, most of the respondents in intervention group are satisfied (80\%), and control group are quite satisfied $(88.57 \%)$.

Table 3.

The distribution of the average family satisfaction in Kramat Jati, East Jakarta (intervention group) and South Jakarta (control group) in 2012

\begin{tabular}{llcccccccc}
\hline No & Variable & Group & Mean & SD & $\begin{array}{c}\text { Mean } \\
\text { Dif }\end{array}$ & $\begin{array}{c}\text { Minim } \\
\text { al- } \\
\text { Maxim } \\
\text { al }\end{array}$ & 95\% CI & $P$ \\
\hline 1 & Family & Intervention & 3.09 & 0.46 & 1.09 & 35 & $2-4$ & $2.93-3.24$ & 0.000 \\
& satisfaction & Control & 2 & 0.34 & & 35 & $1-3$ & $1.88-2.12$ &
\end{tabular}

From Table 3, the difference of the mean values of family satisfaction at intervention group and control group was $1.09(\mathrm{p}=0.000)$ with Mann Whitney test. It showed significant differences in level family satisfaction in intervention and control group. 
Table 4.

The distribution of the family nursing care, health information, communication inter health care, and information management in health care in Kramat Jati, East Jakarta(intervention group) and South Jakarta (control group) in 2012

\begin{tabular}{|c|c|c|c|c|c|c|c|c|c|}
\hline No & Variable & Group & Mean & SD & $\begin{array}{c}\text { Mea } \\
\text { n } \\
\text { Diff }\end{array}$ & $\mathbf{n}$ & $\begin{array}{c}\text { Minima } \\
\text { l- } \\
\text { Maxim } \\
\text { al } \\
\end{array}$ & $95 \%$ CI & $P$ \\
\hline 1 & $\begin{array}{l}\text { Family } \\
\text { Nursing Care }\end{array}$ & $\begin{array}{c}\text { Intervention } \\
\text { Control }\end{array}$ & $\begin{array}{c}27.4 \\
21.11\end{array}$ & $\begin{array}{l}2.09 \\
0.47\end{array}$ & 6.29 & $\begin{array}{l}35 \\
35\end{array}$ & $\begin{array}{l}23-31 \\
21-23\end{array}$ & $\begin{array}{c}26.7-28.1 \\
20.95-21.28\end{array}$ & 0.000 \\
\hline 2 & $\begin{array}{l}\text { Health } \\
\text { Information }\end{array}$ & $\begin{array}{c}\text { Intervention } \\
\text { Control }\end{array}$ & $\begin{array}{l}21.6 \\
15.7\end{array}$ & $\begin{array}{l}1.63 \\
1.18\end{array}$ & 5.9 & $\begin{array}{l}35 \\
35\end{array}$ & $\begin{array}{l}19-24 \\
12-17\end{array}$ & $\begin{array}{c}21.03-22.16 \\
15.3-16.1\end{array}$ & 0.000 \\
\hline 3 & $\begin{array}{l}\text { Information } \\
\text { management } \\
\text { in health care }\end{array}$ & $\begin{array}{l}\text { Intervention } \\
\text { Control }\end{array}$ & $\begin{array}{l}11.3 \\
8.54\end{array}$ & $\begin{array}{c}1.28 \\
0.5\end{array}$ & 2.76 & $\begin{array}{l}35 \\
35\end{array}$ & $\begin{array}{c}9-14 \\
8-9\end{array}$ & $\begin{array}{c}10.87-11.75 \\
8.3-8.7\end{array}$ & 0.000 \\
\hline & $\begin{array}{l}\text { TOTAL } \\
\text { SCORE } \\
(20-80)\end{array}$ & $\begin{array}{c}\text { Intervention } \\
\text { Control }\end{array}$ & $\begin{array}{c}60.34 \\
45\end{array}$ & $\begin{array}{l}3.4 \\
1.4\end{array}$ & 15.34 & $\begin{array}{l}35 \\
35\end{array}$ & $\begin{array}{l}53-67 \\
41-49\end{array}$ & $\begin{array}{c}59,17-61.5 \\
44.88-45.86\end{array}$ & 0.000 \\
\hline
\end{tabular}

From Table 4, the difference of the mean values of family nursing care at intervention group and control group was $6.29(\mathrm{p}=0.000)$, health information was $5.9(\mathrm{p}=0.000)$, information management in health care was 2.76 $(\mathrm{p}=0.000)$, and difference man of total score was 15.34 with Mann Whitney test. It showed significant differences in level family satisfaction in intervention and control group.

Table 5.

The distribution of the family expectation in Kramat Jati, East Jakarta(intervention group) and South Jakarta (control group) in 2012

\begin{tabular}{llcccccccc}
\hline No & Variable & Group & $\begin{array}{c}\text { Mean } \\
\mathbf{( 5 - 2 0 )}\end{array}$ & SD & $\begin{array}{c}\text { Mea } \\
\mathbf{n} \\
\text { Diff }\end{array}$ & $\begin{array}{c}\text { Minima } \\
\mathbf{l}- \\
\text { Maxima } \\
\mathbf{l}\end{array}$ & 95\% CI & P \\
\hline 1 & Family & Intervention & 17.97 & 1.36 & 0.93 & 35 & $15-20$ & $17.5-18.4$ & 0.004 \\
& expectancy & Control & 18.9 & 0.85 & & 35 & $17-20$ & $18.6-19.2$ & \\
\hline
\end{tabular}

From Table 5, Family expectation involve the wishes or expectations of the role of family caregivers, including family wishes that the family nurse service fees charged to the government, felt the need to visit family caregivers, get good information from family caregivers, to help care for a family member, can tell you about health problems of family caregivers, and know the results of the development of the health of every month. The difference of the mean values of family expectation at intervention group and control group was 0.93 , control group higher expectation than intervention group $(\mathrm{p}=0.004)$ with Mann Whitney test. It showed significant differences in level family satisfaction in intervention and control group.

Result of research showed that level of satisfaction family was higher at families have got a information technology based family nursing care by Mann Whitney test $(\mathrm{p}=0.000)$. But only one community health center that carried the family nursing care based on information technology. There are many other community health centers in need computer based documentation. However, people still need care nursing practice better family. Families expected the government to bear the burden of the cost of public health. Nursing information technology supported nursing care documentation, which affected the quality and continuity of family centered nursing care.

\section{Discussion}

Satisfaction is one of the most important outcomes and there have been no systematic studies investigating the effect of family related variables on family satisfaction with care (6). Satisfaction is a comparison between the perceptions of services received and his expectations before using these services (7). 
Families as recipients of health care services will expect to be able to provide health care services quality health and able to provide the best health care services in accordance with expectations. Information technology based family nursing care is an important aspect to provide high quality nursing care and can improve the level family satisfaction was 15.34 points higher than control group $(\mathrm{p}=0.000)$. This is, consistent with research conducted by Marita, et al (2002) which states that the significant determinants of family satisfaction: nursing system (6).

Family-centered care is an innovative approach to the planning, delivery, and evaluation of health care that is grounded in mutually beneficial partnerships among health care patients, families, and providers (8). Health informatics, particularly advances in technology has the potential to facilitate patient centered care (9). Therefore, to improve family nursing care can be done by improving nursing documentation system. Currently, a good documentation system by using computer-based information technologies. With good information system, can improve communication in the health care team. The application of information technology is not fully supported at the primary care level. The first application computer based documentation in health center community in Puskesmas Kramat Jati, Jakarta Timur in Indonesia. Result of research that documentation is very important to use the computer in providing health services in the community. By good documentation management system, people can easily get health care without having to go through a complicated bureaucracy.

Currently in Indonesia, generally family nursing care is still not as expected. Family expectation for the family nursing care was very high in 17.97 at intervention group and 18.9 at control group (scale 5-20). This shows the highest family expectations against family nursing care quality. This should be supported by the government to serve its citizens. Indonesia's health focus is still on the treatment. Promotion and prevention efforts are still in their infancy. This leads to a family nursing care given not to the expectations of society. Family hopes that family nursing financing charged to the government. Families expected the government to bear the burden of the cost of public health.

However, the health information technologies deployed as part of the national framework must support nursing practice in a manner that enables prevention of medical error and promotion of patient safety and contributes to the development of practice-based nursing knowledge as well as best practices for patient safety (10). In addition we look at the level of family satisfaction and family wishes for family nursing care, information technology in family nursing care is essential in improving the quality and continuity of nursing care.

\section{Conclusion}

The results of study showed the importance of nursing documentation using information technology, which improved the quality and continuity of family nursing care, and finally increased family satisfaction. This result is only applied for one primary health care center, however this positive results suggested that nursing documentation using Management Nursing Information System (MNIS) to be applied for other primary care centers in Indonesia.

\section{Acknowledgments}

We would like to thank Directorate of Research and Community Services UI for The International Collaboration Research Grant, FON UI and FON Kitasato University. Also thanks to Central Health Community Kramat Jati, East Jakarta, Indonesia.

\section{References}

[1] Ammenwerth, E., Mansnamm, U., Iller, C., \& Eichstadter, R. Factors affecting and affected by user acceptance for computerbased nursing documentation: Results of a two year study. JAMIA, 10, 2003, 69-84.

[2] Hariyati, Rr T. Management Nursing Information System in Indonesia. Nursing Journal Indonesia, 6 (1), 2004.

[3] Manuama, E.O., Oktarina, M., Chandra Y.A., Astuti Yuni Nursasi. Description of the needs of the families in the village nursing services in Ratu Jaya, Depok. Student's final paper in Faculty of Nursing Universitas Indonesia, 2010.

[4] Hariyati, Rr. T. Corelation between legal aspect knowledge and quality of nursing documentation. Nursing Journal Indonesia, Vol. 6, 2001.

[5] Henry S. B. Informatics: essensial infrastructure for quality assessment and improvement in nursing. JAMIA, 2, 1995, 169-182

[6] Morita T., Chihara S., Kashigawa T. Family satisfaction with inpatient palliative care in Japan. Palliative medicine, 16, 2002, 185193

[7] Sutriyanti Y., Kelliat B.A., Pujasari H. The influence of Nurse caring behavior training to the patients and their family satisfaction in Curup General Hospital. Thesis Master of Nursing Science, Universitas Indonesia, 2009.

[8] Folz, Emma Ranate. A family centred care partnership for patient transfer at the Alberta Children's Hospital. ProQuest Dissertation and theses: The sciences and engineering collection, 2011.

[9] Snyder C.F., Wu A. W., Miller R.S., Jensen R.E., Bantug E.T., Wolff A.C. The role of informatics in promoting patient-centered care. The Cancer Journal, 17(4), 2011, 211-218.

[10] Bakken, Suzanne. Informatics for Patient Safety: A Nursing Research Perspective. Annual Review of Nursing Research, 24, 2006, ProQuest, pg. 219 